Małgorzata M.E. Czerny (D) https://orcid.org/0000-0002-5838-8322

\title{
Religion as a Source of Islamic Ethics and its Impact on the Islamic Accounting System
}

\begin{abstract}
: The article introduces religion as a source of Muslim ethics and shows how it is shaping the system of Islamic accounting and the ethical behaviour of Muslim accountants. Cultural differences are an increasingly important factor to be taken into account in running a business. They are also the subject of scientific research, for example, in the context of their impact on the development of accounting systems in various cultural circles. The relevant reference literature and the Qur'an were used for qualitative analysis carried out by means of induction and deduction methods.The analysis conducted indicates that although the scope of ethical codes in Muslim and non-Muslim countries is very similar, in the case of Islam, its message is strengthened by religion seen as a source of law as well as professional ethics. This means that the legal sanctions envisaged for breaking the rules are accompanied by the fear of being excluded from the community and losing an opportunity for salvation. This article can fulfill an informative role, allowing the reader to understand the reasons for some differences in perceiving ethical issues and the way of doing business in different cultural circles.

Keywords: $\quad$ Islamic ethics, Sharia, Islamic accounting

JEL: M41, F69
\end{abstract}




\section{Introduction}

Accountability may be defined as 'the fact or condition of being accountable,' whereby accountable means 'required or expected to justify actions or decisions' or simply 'responsibility.' In the accounting profession, the main objective is 'to aid accountability' (Lewis, 2001). Therefore, the International Federation of Accountants (IFAC) has set up the International Standards of Ethics for Accountants (IESBA) to develop and issue high-quality ethical standards to be used worldwide for professional purposes. The publication contains five sections on general ethical requirements. It includes integrity, professional competency and due care, confidentiality and professional behaviour, emphasising the importance of being straightforward, honesty, fair dealings, and truthfulness. An accountant must also make professional judgments without prejudice, conflicts of interest or excessive influence of others. In terms of competence, accountants must maintain professional knowledge and skills, as well as conscientiously apply all standards in their services. An accountant must also maintain confidentiality without disclosing any information to outside companies and refraining from using it for personal gain. When it comes to professional behaviour, an accountant should avoid any action that would discredit the profession.

In Islam, the meaning of accounting is accountability and the concept of accountability is fundamental (Napier, 2009; Noor Lela, Ahmed, Wan Salmuni, 2017). Being 'accountable' from the Islamic point of view means the responsibility of an individual to Allah in all endeavors. This brings about the notion of trustee (khalifah or vicegerent), as everything in this world is provided by Allah for the mankind, hence, human beings are responsible for the way they derive benefits from it (Alani, Alani, 2012). Trust is a very important issue in Muslim beliefs, which is clearly shown in Surah Al-Anfal (Święty Koran..., 1990; 8: 27): 'O you who believe! Betray not Allah and His Messenger, nor betray knowingly your Amanat (things entrusted to you, and all the duties which Allah has ordained for you).'

Responsibility is an ethical value that benefits not only an individual but society as a whole. When an individual performs his or her duties, effects are communicated to the public. Therefore, if the duty is fulfilled in a good way, society also benfits from it and vice versa.

The notion that self-interest prevails over ethical judgment is not new. Studies indicate that self-interest is one of the main factors of ethical failure (Jackling et al., 2007). There are also other factors that can affect morality (a lack of independence, a lack of ethical sensitivity, and a lack of objectivity) (Elias, Farag, 2010; Alani, Alani, 2012). In the Islamic law (Sharia), the accounting profession is a fardkifayah, which means 'a collective religious duty.' When some Muslims have fulfilled the duty, this fact exempts others from doing it, but if no one does it, then it becomes a sin of the entire community (Alani, 
Alani, 2012). In Islam, the act of recording and fair measurement has been repetitively mentioned in the Qur'an (for example, verse 282 of Surah Al-Baqarah mentions the need to write down a debt for a fixed period but also the responsibility of the scribe), which proves that problems of ethics or morality were present in an Islamic economy 1400 years ago. At present, the code of ethics established by the Islamic Financial Institutions Accounting and Audit Organisation (AAOIFI) applies to internal accountants, and any other additional codes can only be applied if they are not contrary to Sharia rules and principles. The code was introduced as a measure 'aimed at developing the ethical awareness of accountants about current practices and their compliance with the Sharia principle, and ensuring the accuracy and reliability of accounting information presented in the financial statements.' According to this, the code contains three sections: the Sharia foundations of accountants' ethics, principles of ethics of accountants, and rules of ethical conduct for accountants. In Sharia, morality (or ethics) is highly valued as consistent with the hadiths: 'I have been sent to complement the most noble morals' (Alani, Alani, 2012: 28).

In the article, sources of Islamic ethics and its most significant features are examined in the context of accounting and its role in Muslim society as well as the role and duties of accountants in Muslim countries. A comparison between Islamic accounting ethics and professional codes (US and international) is also conducted. The paper aims to show the Muslim point of view on ethics in accounting and how religious beliefs that are the foundation of Sharia law as well as the basis for the Muslim code of ethics are shaping ethical behaviour of Muslim accountants and the accounting system in Islamic countries, its role and main tasks. First, it is necessary to present some dogmas of Islam and their impact on Sharia, as Islamic law and ethics have the same sources, and Sharia is closely connected with the Muslim ethical code.

\section{Islamic law - Sharia and its religious sources}

The following five dogmas are the basis of the faith of Muslims: the faith in one God; the faith in the existence of angels; the faith in the holy books: the Torah, Gospel, and Qur'an; as well as the faith in God's messengers and the Last Judgment Day (but also paradise, hell and destiny: gada and gadar). Each believer should perform individually five duties (Faraid). These duties are arkanad-din (pillars of faith) and include (Danecki, 2007; Bonca, 2010; Al-Kaber, 2013):

- shahada (confession of faith in one God);

- salat (prayer - a Muslim has the duty of praying five times a day, faced towards Mecca); 
- saum (fasting - from dawn to dusk for all days of the ninth month of the Muslim year, Ramadan);

- zakat (alms);

- hadj (a pilgrimage to Mecca which every Muslim should make once). Islamic law is the key to understand the nature of Muslim society and also the culture of Islam in general. It is closely related to religion, so the legal regulations are basically religious sanctions. The basic sources of Islamic law are (Danecki, 2007; Al-Kaber, 2013): - The Qur'an, divided into 114 Surah (chapters), which is not only the Holy Book of Revelation but also the basis of all elements of Islam: its law, as well as the social, political and religious system, culture, art, and science.

- The Sunnah of the Prophet Muhammad (also called the Tradition), which is the second, written source of Muslim culture. The Sunnah, before it became a legal term, meant the 'path,' and defined a set of messages concerning the life and conduct of Muhammad, which were determined by the hadiths (the reflection of words, actions, and the silent approval of Muhammad).

The Qur'an and Sunnah together are the main sources of the sacred law of Islam (Sharia). The third element is the legal doctrine: fiqh, ijtihad, qijas, and ijma. These are secondary sources of rules and regulations regarding all events and problems (Al-Kaber, 2013). Fiqh, or the science of Islamic law, was initially defined just as knowledge. Danecki (2007) states that today Sharia presents a more practical approach, while fiqha reflects a theoretical approach. Ijtihad is a legal doctrine to solve emerging issues and problems. Qijas is the solution of the situation by analogy in the light of the Qur'an and Sunnah. Finally, ijma is the resolution of the doctrine based on a consensus on matters not regulated directly by the Qur'an (Jabłońska-Bonca, 2005).

\section{Sources of Islamic ethics}

Muhammad, as a Prophet, taught that: 'Strong faith generates a strong character, and the collapse of morality is due to the weakness or loss of faith' (Saadeh et al., 2016). In Islam, according to religious sources such as the Qur'an and Sunnah, there is a strong conviction that a believer's worship is a form of ethics and that morality (ethics) is a form of worship (Saadeh et al., 2016).

'Ye have indeed in the Messenger of Allah a beautiful pattern (of conduct) for any one whose hope is in Allah and the Final Day, and who engages much in the Praise of Allah' (Święty Koran..., 1990: 33: 21). 
This verse means that the ultimate aspiration of a believer is to please God, since one's faith in God and the Day of Judgement leads to ethical behaviour and guides to an ethical act. From here, it is possible to categorise the principles and rules of ethical behaviour among Muslims into three levels (Al-Ghazali, 2001):

- coming from arkanad-din (pillars of faith);

- coming from iman (faith);

- coming from ihsan (excellence).

The pillars of faith are here a kind of basis. They contain spiritual, devotional, social, and economic dimensions. They affect conduct between a believer and Allah as well as other people. As explained by Saadeh et al. (2016), worship loses its meaning if it has no bearing on the behaviour of Muslims.

Shahada, as the testimony that there is no god but Allah and that Muhammad is the Messenger of God, distinguishes between infidelity and faith. Salat (the prayer) prevents from Al-Fahsha and Al-Munkar (i.e. great sins such as disbelief, polytheism, and every kind of evil wicked deed): 'Recite (O Muhammad) what has been revealed to you of the Book (the Qur'an), and perform prayer (Iqamat-as-Salat). And Allah knows what you do' (Święty Koran..., 1990: 29: 40).

Three other pillars of Islam also are connected with some ethical warrants and instructions. In verses about alms (zakat), for example, we can read: '(They are) those who, if We establish them in the land, establish regular prayer and give regular charity, enjoin the right and forbid wrong: with Allah rests the end (and decision) of (all) affairs' (Święty Koran..., 1990: 22: 41).

According to comments made by Saadeh et al. (2016), in the sections of the Qur'an dedicated to saum and hadj, Muhammad concluded: 'Whoever does not give up false speech and evil actions, Allah is notin need of his leaving his food and drink' and 'Whoever performed Hadj and did not utter a bad word or commit an immoral act will be like the day his mother born him.' These verses of the Qur'an clearly state that simply carrying out religious obligations and ceremonies, such as fasting and pilgrimage without moral (ethical) behaviour has little or no meaning in the eyes of God. It leads to the second stage of rules - iman.

The faith is essential for Muslim society: 'Only those are the believers who have believed in Allah and His Messenger, and afterward doubt not but strive with their lives for the Cause of Allah. Those! They are the truthful' (Święty Koran..., 1990: 49: 15).

Considering the teaching of Muhammad: 'Three things characterise a hypocrite even if he prays, fasts, performed hadj and calls himself a Muslim: If he talks he lies, if he promises he breaches, and if he is entrusted he defrauds,' it is easy to conclude that if a Muslim does not abide by the morality of Islam, he or she has left Islam automatically (Saa- 
deh at al., 2016). Thus the impact of ethics and its importance is recognised by Muslims as more important than the professional code of conduct for an auditor. In Islam, it can be said that ethics and faith are two sides of the same coin.

On the third level, ihsan includes the promotion of virtue and prevention of vice ('Ihsan is to worship Allah as if you see Him, and if you do not see Him, then know that He sees you') (Saadeh et al., 2016). A believer does not worship God to be virtuous, but becomes virtuous to worship God. It can be concluded from the foregoing that the Islamic moral code includes, among others: honesty, belief in the Last Day (Day of Judgement), loyalty and devotion, which somewhat covers the standards of the international codes.

\section{Islamic ethics and accounting and its financial environment}

As demonstrated above, Islam represents moral values derived from a transcendental source - a fundamental concept which is based on the Qur'an (Amin, Abdul Rahman, Abdul Razak, 2013). The Islamic ethical system is based generally on equal, justified, benevolent, and accountable principles. Islam has also its own laws to regulate accounting practices and they are not always similar to western regulations (Napier, 2009). From the Islamic perspective, accounting has always been characterised by ethical principles; a concern about balanced social commitment grounded in the Sharia framework which prohibits the involvement in illegal activities (Saadeh et al., 2016). In the literature, Islamic accounting is defined as a tool that allows Muslims to assess their responsibility towards God in relation to either interpersonal or environmental transactions (Jaworska, 2011). It communicates the economic situation and performance of a business unit, and guarantees that the information is correct, in accordance with Sharia law, and is also free from fraud (Hameed, Yaya, 2011).

Differences between Islamic accounting and conventional accounting are shown in the Table 1.

Table 1. Islamic accounting vs conventional accounting

\begin{tabular}{|c|c|c|}
\hline Differentiating features & Islamic accounting & Conventional accounting \\
\hline \multicolumn{3}{|c|}{ Socio-economic conditions } \\
\hline Legal orientation & Religious law & Common law \\
\hline Philosophy of operation & 'Unity in God' & Economic rationalism \\
\hline Economic approach & Macro & Micro \\
\hline Business basis & Religion & Secularity \\
\hline Economic activity & $\begin{array}{l}\text { Based on the Qur'an's ethical } \\
\text { law }\end{array}$ & Based on commercial law \\
\hline
\end{tabular}


Małgorzata M.E. Czerny | Religion as a Source of Islamic Ethics...

\begin{tabular}{|c|c|c|}
\hline $\begin{array}{l}\text { The dichotomy between } \\
\text { business and morality }\end{array}$ & No & Yes \\
\hline Management goals & $\begin{array}{l}\text { - Responsible profits } \\
\text { - Social benefits } \\
\text { - Social justice } \\
\text { - Natural environment }\end{array}$ & $\begin{array}{l}\text { - Profit maximisation } \\
\text { - Individualisation of bene- } \\
\text { fits }\end{array}$ \\
\hline Responsibility & Public & Personal \\
\hline $\begin{array}{l}\text { The principle of going } \\
\text { concern }\end{array}$ & Based on Islamic law & Based on income \\
\hline Time value of money & No & Yes \\
\hline Interest & No & Yes \\
\hline \multicolumn{3}{|c|}{ Scope/range of accounting and information receivers } \\
\hline $\begin{array}{l}\text { Purposes of providing } \\
\text { information }\end{array}$ & $\begin{array}{l}\text { - Responsibility towards the } \\
\text { laws and orders of Islam } \\
\text { - Orientation towards social } \\
\text { welfare }\end{array}$ & $\begin{array}{l}\text { - Supporting the decisions } \\
\text { of investors and creditors } \\
\text { - Market orientation }\end{array}$ \\
\hline Information users & $\begin{array}{l}\text { - State } \\
\text { - Society }\end{array}$ & $\begin{array}{l}\text { - Managers } \\
\text { - Inverstors } \\
\text { - Lenders }\end{array}$ \\
\hline Accounting policy & Value-oriented & Goal-oriented \\
\hline Accounting principles & Ethical & Technical \\
\hline Accounting ethics & Resulting from religion & Professional \\
\hline \multicolumn{3}{|c|}{ Identification and methods of measurement and disclosure of information } \\
\hline $\begin{array}{l}\text { Type of information to be } \\
\text { identified }\end{array}$ & $\begin{array}{l}\text { Socio-economic and religious } \\
\text { events (financial and non-fi- } \\
\text { nancial nature) }\end{array}$ & $\begin{array}{l}\text { Monetary measurement } \\
\text { of internal economic events }\end{array}$ \\
\hline Measurement & Present value & Historical cost \\
\hline Disclosures & $\begin{array}{l}\text { - Subordinated to the law } \\
\text { of Islam, socio-economic } \\
\text { - Full disclosure }\end{array}$ & $\begin{array}{l}\text { - All material } \\
\text { economic events } \\
\text { - Limited disclosures } \\
\end{array}$ \\
\hline Determining the income & Balance sheet approach & Income-cost approach \\
\hline $\begin{array}{l}\text { Most important financial } \\
\text { statement }\end{array}$ & Balance sheet & Profit and loss account \\
\hline
\end{tabular}

Source: own elaboration on the basis of Jaworska, 2011: 80

This accounting system operates in a specific economic environment. Islamic banking as a part of the Islamic financial system (which also includes religiously-based insurance institutions, a system of wealth redistribution and charities) has been developed as a theoretical concept of Muslim academic circles working on construing a system of capital redistribution that would be compatible with Sharia, an alternative to classical banking developing in Islamic countries. 
In Islamic economic life, only activities in accordance with Sharia have a reason for being, and this also applies to financial activities whose primary goals are education (tarbiyah), justice (adalah), and protection of the public interest (maslahah al-ummah) (Al-Kaber, 2013).

The absence of interest - riba is the most important feature of Islamic banking, which is why it is frequently called interest-free banking. Among Muslims, riba means unearned profit, a percentage of a loan, a charge in addition to the principal. It is not allowed to generate a positive return on borrowed money. Riba can be defined as any value (small or large, monetary or material) exceeding the principal as a condition for obtaining the principal (customarily or established in contract) (Iqbal, Molyneux, 2005). This prohibition of riba is also rooted in the conviction that money is only a medium of exchange, or a way to determine the value of items, with it having no value in itself; therefore, it is not allowed to raise more money by collecting fixed interest on bank deposits or money borrowed from someone else (Al-Kaber, 2013).

In Islam, contracting is of great importance to society. The principle is full freedom of contract. Relations between people and businesses should be transparent and create trust, so information management is of great consequence (Al-Kaber, 2013). It is unacceptable to misinform any party. Thus, leveraging the business privileges ensuing from information asymmetry is the most prohibited practice (Bonca, 2010). This is connected to the concept of gharar, which expresses uncertainty. Uncertainty cannot be completely avoided in any activity. Risk taking is a prerequisite in return for the right to earn a profit. The problem, however, is that the degree of uncertainty in haram (forbidden) transactions is not clearly defined. The Qur'an clearly prohibits all commercial transactions that cause injustice in any form to any party. Gharar refers also to the possibility of fraud, which can result from any contractual party deliberately withholding relevant information. It should be pointed out that, according to this principle, every economic transaction should have the attribute of freedom from risk, uncertainty, speculation, threat, and fraud.

Islam prohibits agreements in which speculation (al-qimar) and unearned income (al-maysir) occur. This standard is based on the principle of 'uncertain benefits,' which may even prohibit the repayment of borrowed capital plus an amount to offset the effects of inflation (Al-Kaber, 2013). Therefore, futures and options are forbidden, as they are instruments that guarantee a future level of income or cost. These prohibitions prevent also the trading of debt and the use of derivatives (CDS) by parties that do not have certain goods, but who hope to obtain them through speculation. Short sales are also prohibited, except in the form of salam and istisna where goods are not currently available and must be produced before delivery (Korenik, 2010: 550). Also, payments of any pre-determined amount in excess of the current principal are forbidden. Islam allows 
only one type of loan (qard-hasan), according to which the lender does not charge any interest or amounts on top of the money lent. This principle comes from a verse stressing that any benefits, even if they are indirect, are prohibited (Al-Kaber, 2013: 183).

Islam encourages Muslims to invest their money and become partners to share not only profits but also risk. According to Sharia, the Islamic financial system is based on the belief that the lender should act as a co-participant, not just as a creditor (an investment can benefit society this way). The bank and borrower should be responsible for the risk but also partake in the profits generated by a given venture. This is different from the commercial banking system based on charging interest. In this system, all the responsibility is taken by the borrower who must return the loan with interest, regardless of whether the venture is profitable or not. Islam does not give investors any other alternative (Al-Kaber, 2013).

Islamic law treats money as potential capital, not as equity. This means money becomes capital only when it is invested. Thus, money (in the form of a loan) intended for a venture is considered to be a debt to a given venture. Muslims are encouraged to make purchases and are advised not to store money unproductively. For that reason, it is not acceptable to amass money. In Islam, money represents purchasing power and only this use of money is appropriate. Purchasing power cannot be used to acquire more purchasing power (more money) without using it to buy goods or services.

According to these rules, banks operating in Muslim countries had to invent techniques and instruments so as not to violate Sharia. The most popular one is a Murabahah contract (cost-plus or mark-up), i.e. the sale of goods at a price that includes the expected profit known to the seller and buyer alike. The price is usually paid by the buyer in deferred payments. Under the Murabahah rules, Islamic banks buy goods an importer or customer needs on their own behalf and subsequently re-sell them at a higher fixed price. A bank's profits come from giving a particular service in which it was bound to incur a given risk. Even though there exists high probability of earning a profit when the bank takes this risk, the profit is still considered to be legal. It is also important to note that only a legitimate profit added to the right price is considered to be permissible by Islamic law. Any additional increase of the deferred payments is unacceptable because it would be tantamount to the value of money changing over time, and thus to charging interest (Al-Kaber, 2013).

Another instrument is Mudarabah (passive partnership). It establishes a contract between two entities in which one of them, Rabb al-Mal (the principal), entrusts money to the Mudarib (the manager). The Mudarib should use the money in a certain way and then return it to Rabb al-Mal along with a pre-determined part of the earned profit. The former retains the remaining part of profit. Profits are divided among entities in the proportions agreed in the contract, but financial losses are borne only by the princi- 
pal. It creates interest in profiting concerning both sides of the bank's balance sheet, i.e. liabilities and assets. This feature produces several positive effects enhancing efficiency, equity and stability of the banking system (Iqbal, Molyneux, 2005).

The third instrument is Musharakah (partnership) - a financial instrument considered to be the best fit for meeting the Islamic principle of equal profit sharing and risk taking. Participation in Musharakah may involve a new venture or additional funds for an existing one. Profits are divided according to pre-determined conditions, and losses are borne in proportion to the capital invested. In this case, the bank and the customer share their equity in the company as well as the management of a given venture, they share the profit or loss according to the value of the shares held. The features of Musharakah are as follows (Adamek, 2008: 226):

- contracts are aligned to the requirements formulated by their parties;

- it is based on ethical and moral principles, as profit and loss sharing (PLS) forms the foundation for drafting the principles used in contracts;

- it has a practical orientation towards supporting short-term capital needs, contrary to the way that similar contracts are usually applied in accordance with their historical assumptions and essence.

Apart from these three types of contracts, Islamic banks offer a few other instruments and techniques, such as ijarah, bai salam and bai muajjal, istisna, and qard-hasan.

Ijarah is a lease. An operational lease with an option to purchase the leased asset at the end of the contract does not raise any religious reservations, but financial leases do cause doubts. According to some views, it is acceptable if certain conditions are met (Al-Kaber, 2013: 188):

- the lessor must bear the risk of the lease as the object's true owner; it is not acceptable for the lessor to act as an intermediary between the manufacturer and the lessee because then the lessor would not take any risk (ownership would de facto secure a loan);

- payments cannot start before the lessee takes possession of the object and should not last longer than the subject of the lease is suitable for use;

- the lessor should be responsible for all manufacturing defects (and other damage not attributable to the lessee), though the lessee must take care of the leased object. From the point of view of Islamic jurisprudence, ijarah is perceived as the sale of the right to use someone else's property, and therefore, the rules of this sale are classified as ordinary trade, which is acceptable. Ijarah is a very efficient instrument facilitating the provision of funding for business development (Bonca, 2010: 144).

Bai is a purchase-sale agreement in which there are normally two sides - the seller who offers goods for sale and the buyer who is willing to pay a price, mostly in cash - established by the two parties for the goods being offered. A model bai is the transfer of goods to the buyer in return for payment to the seller. This situation, however, is rare 
in practice when it comes to professional transactions. Situations frequently occur when the parties agree to postpone payment or delivery of goods. Therefore, instruments were created to modify bai to facilitate these transactions (Bonca, 2010). The first one is bai muajjal. It means financing the acquisition of assets through deferred repayment. It is a financial technique adopted by Islamic banks in the form of Murabahah. According to the guidelines of this contract, the bank determines the time and method of payment with the client. Then certain assets are bought and sold at a fixed price, consisting of the cost of assets and the margin charged by the banks. Another is bai salam, a contract in which payments for goods are meant to be delivered to the buyer at a later date. It is necessary to determine the quality of the goods to eliminate any doubt that could lead to disputes. Goods are the subject of sale, though gold, silver and currencies cannot be sold. Bai salam transactions are limited only to the exchange of products whose quantity and quality can be precisely defined at the time the contract is concluded (Rahnema, 1994).

Istisna is a contract similar to a commercial contract in which a bank orders goods from a manufacturer with pre-determined properties at a pre-determined price. The bank pays all or part of the price before receiving the finished product (Czerniak, 2010: 20).

The last Islamic technique used by Muslim banks is qard-hasan (a good-will loan) in which the debtor is obliged to return the amount borrowed. Some Islamic religious scholars point out that the debtor should also cover the administrative costs associated with providing financial support in the form of qardhasan. Muslims believe that this is the only type of loan that does not violate the riba prohibition because it does not really compensate the creditor for the time value of money (Al-Kaber, 2013: 190).

Operating in this financial environment, according to Sharia law, Islamic accounting considers the whole community of believers (umma) as a group of information receivers. This responsibility to God and umma is connected with achieving profits in an ethical way, as well as with the division of wealth between society members. Ethical principles define what is true, just and right, specify the nature of corporate responsibility towards God, as well as priorities for society (Sari Wahyuni, Fernando, Hasnita, 2018).

Thus, Islamic accounting is based on (Abdul Rahman, 2010; Jaworska, 2011; Czerny, Mazurowska, 2019):

- religious law (a value-oriented accounting policy, accounting principles more religious than technical);

- public accountability;

- ownership theory (in Islam, there is no separation between an enterprise as an economic entity and its owner, who as the owner of assets is responsible for liabilities and receivables - it is considered to be immoral to release the owner from liability for company debts while maintaining the right to profit, as a kind of forbidden speculation - the possibility of obtaining benefits excessive in relation to the risk undertaken); 
- management goals such as: responsible profits, social benefits, social justice, and the natural environment.

That determines the macroeconomic approach in Islamic accounting. Also, a consequence of adopting the theory of ownership is recognising the static approach of Islamic accounting (the balance sheet as the most important among financial statements).

Islamic accounting identifies, measures and presents socio-economic and religious events and transactions (financial and non-financial) based on Sharia rules. In fact, Islamic ethical principles seek to respect the right of shareholders and the user of accounting information as well as avoiding exploitations and harm (Abu-Tapanjeh, 2007). Besides, Islamic ethics in accounting practices provides truthfulness, fairness and justice principles to ensure right and honest information for the user: 'Give full measure when you measure, and weigh with a balance that is straight, that is the most fitting and the most advantageous in the final determination' (Święty Koran..., 1990: 17: 35).

All forms of exploitation and activities that are detrimental to society are prohibited in the Islamic ethical system. Islamic users of financial information must avoid transactions with companies that are involved in activities illicit to Muslims (e.g.: gambling, liquor and alcohol, prostitution, or riba or interest) (Alduaimi, 2016). Therefore, using the accounting system, Islamic business units should disclose:

- all economic transactions carried out and prohibited by the Qur'an (full disclosure if a given activity/transaction is haram, so forbidden, or halal, so allowed);

- the obligations derived from zakat (a tax being a contribution to society, at the same time treated as alms) and the basis for its calculation;

- activities in the area of social responsibility (environmental protection, charity acts, shaping desired relationships with employees; the going concern principle is based on Sharia).

This way, Islamic ethics helps in increasing stakeholders' confidence and trust by ensuring that the accounting profession follows Sharia law.

The interaction between a company and its environment must be closely monitored and the company's profitability is a derivative of responsible management of assets and liabilities, maintaining the balance between them (Czerny, 2016: 118). Hence, the cost determination takes place in the balance sheet approach. The religious prohibition of riba and gharar (interest charged on loans and speculation) produces interest-free operations as well as a lack of taking into account the value of money in time. In Islamic accounting, historical cost is not used for valuation but the current value. From the Islamic point of view, the historical cost distorts the value of the obligations arising from the payment of zakat. 


\section{Islamic ethics and accountants}

Accountants, like other Muslims, must perform their duties in accordance with the principles and laws of Islam and base their actions on Islamic ethical standards (Noor Lela, Ahmed, 2017; Noor Lela, Ahmed, Wan Salmuni, 2017) to reduce the possibilities of unethical conduct. The awareness starts with individuals' realisation that they will be accountable for their deeds because God knows everything. That is why Beekun and Badawi (2005) have indicated that religion is one of the most important factors influencing ethical behaviour and judgment. It can be said that religion (and Islamic ethics has its roots in religion) is a moral filter for an accountant which helps in fair, honest and just accounting practice that strengthens integrity and accountability (Ladewi, 2014).

Accountants play a significant role in Muslim society by providing trustful accounting information to Muslim users (Basri, Abdul Khalid, 2012). Accountants must be trustful and fair when preparing financial statements for the benefit of the user of accounting information to achieve Falah (salvation) (Hossain, Karim, Islam, 2008; Noor Lela, Ahmed, Wan Salmuni, 2017); an accountant should ensure the quality of financial information and has the responsibility to prepare fair and high integrity accounting data (Low, Davey, Hooper, 2008). Many aspects of modern and global business activities (financial planning, investments, loans, auditing, and taxes) rely critically on the accounting profession (Ali, Al-Aali, 2015; Noor Lela, Ahmed, Wan Salmuni, 2017; Hajiha, Rajabdorri, 2018). Thus, accountants' task is to clearly communicate the information useful for decision-making purposes and prepare financial statements relying on the principles of justice, trust, fair, integrity, and reliability for precise decision making.

Integrity is a very important value in Islam, as believers are required to be honest and truthful in their actions. To achieve this, accountants have to be well-oriented in their discipline and able to exercise authority with high competency: 'to give back the trust to whoever has entrusted you with it' (Alani, Alani, 2012: 29). Another feature to be emphasised is the above-mentioned vicegerency (khalifah) and accountability (responsibility). Humans took on the responsibility of being khalifah in this world, as is said in verse 72 of Surah Al-Ahzab: 'Truly, we did offer Al-Amanah (the trust or moral responsibility or honesty and all the duties which Allah has ordained) to the heavens and the earth, and the mountains, but they declined to bear it and were afraid of it (i.e. afraid of Allah's torment). But man bore it. Verily, he was unjust (to himself) and ignorant (of its results)' (Święty Koran..., 1990: 33: 72).

Undertaking the responsibility means that people had to 'develop this world' to fulfil their needs and will be held accountable for how they develop it. From the accounting perspective, this means that persons in the accounting profession should constantly im- 
prove their ethical standards simply because they are responsible for that before God, not only because they may expect some legal consequences for unethical deeds (Alani, Alani, 2012).

Other important features required under Sharia are accountants' sincerity, piety and righteousness.

\section{A comparison of the standards of Islamic behaviour and standards of professional codes of conduct (US and international)}

The application of religious ethics among Muslim auditors and introducing it into the conduct of non-Muslim auditors is a religious duty and part of the Islamic faith. This ethics is a part of the Islamic faith, and the task of its learning and applying begins from the moment of birth and continues until death. It is both the duty and the right of Muslims for which they are held accountable 'in this world and the Hereafter': 'The Almighty said: Then, shall ye be questioned that Day about the joy (ye indulged in!)' (Święty Koran..., 1990: 102: 8).

Religious rules are usually stronger than other ethics and superior in the case of real believers. The implementation and monitoring of Islamic ethics begin with an individual and extend to society: 'On no soul doth Allah Place a burden greater than it can bear. It gets every good that it earns, and it suffers every ill that it earns' (Święty Koran..., 1990: 2: 286).

The absence of these ethical standards questions the faith of a Muslim and his or her association with Islam. If the Prophet said: 'The first thing to disappear from your religion will be trust, and the last will be prayer. Whosoever has abandoned prayer has left the religion' (Saadeh et al., 2016: 41), then Muslims have no other choice but agree that their ethics must be managed; this hope will be addressed and fulfilled by the adoption of religion to do that.

Table 2 presents a comparison between Islamic moral behaviour (in the context of accounting), having its roots in religion, and international codes of ethics (including the US code).

Table 2. Islamic ethics vs professional codes of ethics (US and international)

\begin{tabular}{|l|l|l|}
\hline \multicolumn{1}{|c|}{ Aspect of Comparison } & \multicolumn{1}{c|}{ Islamic Ethical Behaviour } & \multicolumn{1}{c|}{ Professional code } \\
\hline Source & Qur'an and Sunnah & Professional bodies \\
\hline Evidence & Muhammad's teaching & $\begin{array}{l}\text { Standards of professional } \\
\text { conduct }\end{array}$ \\
\hline $\begin{array}{l}\text { The reason for its strength } \\
\text { and compliance of profes- } \\
\text { sionals }\end{array}$ & $\begin{array}{l}\text { God knows everything } \\
\text { and judges all }\end{array}$ & $\begin{array}{l}\text { Keep up with the profession- } \\
\text { al rules for the community's } \\
\text { acceptance }\end{array}$ \\
\hline
\end{tabular}


Małgorzata M.E. Czerny $\quad$ Religion as a Source of Islamic Ethics...

\begin{tabular}{|c|c|c|}
\hline Extent of compliance & $\begin{array}{l}\text { Part of the Islamic faith, } \\
\text { pleasing Allah. Worship } \\
\text { manifests in ethics and ethics } \\
\text { manifests in worship }\end{array}$ & $\begin{array}{l}\text { Upright behaviour and } \\
\text { quality audit }\end{array}$ \\
\hline Its persistence & 'To the Day of Resurrection' & Adjusted each period \\
\hline Outcomes & Conscience & A desire to obtain ISO \\
\hline The level of ethics & $\begin{array}{l}\text { The ethics of the prophets } \\
\text { and believers }\end{array}$ & Professional ethics \\
\hline Number of standards & $\begin{array}{l}\text { Level I: the pillars of Islam } \\
\text { Level II: the attitude } \\
\text { of the believers, seventy-odd } \\
\text { division } \\
\text { Level III: ethics benefactors, } \\
\text { to worship Allah }\end{array}$ & $\begin{array}{l}\text { International standards } 5 \\
\text { US standards } 6\end{array}$ \\
\hline $\begin{array}{l}\text { Monitoring its } \\
\text { application }\end{array}$ & Allah, umma & $\begin{array}{l}\text { Members of the profession } \\
\text { and society }\end{array}$ \\
\hline Learning period & $\begin{array}{l}\text { The whole life - from birth } \\
\text { till death }\end{array}$ & $\begin{array}{l}\text { During the practice } \\
\text { of the profession }\end{array}$ \\
\hline Penalties for violators & $\begin{array}{l}\text { In this world and afterlife: } \\
\text { 'of fraud not one of us, and } \\
\text { is a hypocrite' }\end{array}$ & $\begin{array}{l}\text { A punishment (penalty) } \\
\text { provided for by law; if fraud } \\
\text { is not discovered, there is no } \\
\text { penalty }\end{array}$ \\
\hline Its future & Continuity & Change \\
\hline Those who comply & All Muslims & Professionals \\
\hline $\begin{array}{l}\text { The level of application } \\
\text { and of support }\end{array}$ & Increased & Decreased \\
\hline
\end{tabular}

Source: own elaboration on the basis of Saadeh et al., 2016: 41

It can be seen that Islamic ethical behaviours have a much more spiritual dimension, which is understandable considering that a background of these actions is the Islamic religion. More emphasis is placed on an individual's conscience and observance of religious teaching, and the pressure is much stronger than in the case of other religions, because breaking the rules excludes the individual from the circle of believers, and thus from the whole community (umma). Since the whole social and economic life in Muslim countries is based on umma, this threat is particularly onerous. There is also an element of fear of punishment in not only mortal life but also in the afterlife. There may be an argument that similar attitudes of believers can be observed in Christianity, especially Protestantism. It has to be remembered though that Islam is a non-compromising religion - there are no 'bad Muslims' poorly performing duties of votaries. Everyone who breaks rules is excluded by this act and has no right to be called a Muslim anymore (automatic act of apostasy). 
Also, external control is significantly wider in the case of Muslim because of the manner in which interpersonal relations and the law are shaped in Islamic countries, really the whole society is interested in the supervision of an individual's acts. Again, there is an element of spiritual threat - God's (Allah) supervision, making the restrictions regarding proper conduct even more categorical.

\section{Conclusions}

The ethical values of accountants are of great importance for an organisation. This is due to the fact that they are responsible for the preparation of a comprehensive financial statement that indicates the performance of the organisation. In addition, they are required to comply with codes of ethics imposed by the IFAC (for non-Islamic companies) and the AAOIFI (mainly for the IFI). After comparing the ethics of Islamic and traditional accountants, it can be seen that the code of ethics followed by both traditional and Islamic accountants is actually very similar (trustworthiness, legitimacy, objectivity, competency, and diligence). The main difference is that in the case of the Islamic ethical code its source is religious, and the specificity of Islam means that it affects very deeply every area of life in Muslim society, also its economic activity. This makes ethics a particularly effective way of dealing with moral corruption and fraud in the accounting profession in Muslim countries, more so than anywhere else. It is not without significance that religion is a source of law in Muslim countries as well. This way, a religious principle is exceptionally consistent in its message with legal sanctions (how important is such a principle is clearly shown in a reservation made by the AAOIFI that the ethical codes practised by traditional accountants worldwide can be practised by Muslims as long as they do not contravene Sharia principles).

Religion is shaping not only law but also a manner of conducting business and maintaining social bonds in Muslim countries. It affects the role of accounting, shaping the system of accounting so that it would meet expectations of information users (a value-oriented policy, a static approach, the scope of disclosure aimed at capturing haram, operations forbidden by Allah). Also, accountants' ethical principles are controlled not only by their superiors, or the professional community, but in a way by the whole umma (and also Allah himself, from their point of view), so they have a strong sense of responsibility to the community and God. Asccountants' unethical behaviour in Muslim countries compared to western ones carries risk of not only bearing legal consequences but also a threat of exclusion from the umma and condemnation in Allah's eyes, beyond the temporal after-effects (condemnation). Accountants do not feel that they can exploit any form of loopholes found. 


\section{References}

Abdul Rahman A.R. (2010), An introduction Islamic accounting theory and practice, Centre for Research and Training, Kuala Lumpur.

Abu-Tapanjeh A.M. (2007), Corporate governance from the Islamic perspective: A comparative analysis with OECD principles, "Critical Perspectives on Accounting”, vol. 20, issue 5, pp. 556-567, https://doi.org/10.1016/J.CPA.2007.12.004

Adamek J. (2008), PLS i jego odwzorowanie w produktach bankowości islamskiej na przykładzie kontraktu musharakah, Wydawnictwo Uniwersytetu Ekonomicznego we Wrocławiu, Wrocław.

Alani F.S., Alani H.K. (2012), The Role of Islamic Ethics in Accounting Environment, "Journal of Business and Management”, vol. 2, issue 1, pp. 26-30, https://doi.org/10.9790/487X-0212630

Alduaimi S. (2016), Fundamental Islamic perspective of work ethics, "Journal of Islamic Accounting and Business Ethics", vol. 7, no. 1, pp. 59-76, https://doi.org/10.1108/JIABR-02-2014-0006

Al-Ghazali (2001), Muslim's Morality, Darul Al-Qalam Publication, Beirut.

Ali A., Al-Aali A. (2015), Marketing and ethics: What Islamic ethics here contributed and the challenges Ahead, "Journal of Business Ethics", vol. 129, pp. 833-845, https://doi.org/10.1007/s10551014-2131-x

Al-Kaber M. (2013), Techniki finansowe banków islamskich, “Optimum. Studia Ekonomiczne”, vol. 3, no. 63, pp. 174-194, https://doi.org/10.15290/ose.2013.03.63.11

Amin H., Abdul Rahman A.R., Abdul Razak D. (2013), An intergrative approach for understanding Islamic financing adoption in Malaysia, "International Journal of Bank Marketing", vol. 31, issue 7, pp. 544-573, https://doi.org/10.1108/IJBM-02-2013-0008

Basri H., Abdul Khalid S.N. (2012), Examining accounting and accountability issues in religious context: insight from literature, "Aceh International Journal of Social Sciences", vol. 1, no. 1, pp. 24-31.

Beekun R., Badawi J. (2005), Balancing ethical responsibility among multiple organizational stakeholders: the Islamic perspective, "Journal of Business Ethics", vol. 60, pp. 131-145, https://doi..org/10.1007/s10551-004-8204-5

Bonca M.A. (2010), Islamskie instrumenty finansowe, Wydawnictwa Akademickie i Profesjonalne, Warszawa.

Czerniak A. (2010), Symptomy kryzysu globalnego a etyka gospodarcza religii światowych. Analiza porównawcza bankowości islamskiej i bankowości klasycznej w kontekście kryzysu finansowego, Szkoła Główna Handlowa w Warszawie, Warszawa.

Czerny M. (2016), Wpływ zasad religijnych na ukształtowanie systemu rachunkowości, "Annales. Etyka w Życiu Gospodarczym", vol. 19, no. 2, pp. 111-128, https://doi.org/10.18778/1899-2226.19.2.08

Czerny M., Mazurowska M. (2019), A possible impact of cultural factors on the expectations on the content of Islamic financial statements, "Problems of Management in the 21st Century", vol. 14, no. 1, pp. 21-31, https://doi.org/10.33225/pmc/19.14.21

Danecki J. (2007), Podstawowe wiadomości o islamie, Wydawnictwo Akademickie DIALOG, Warszawa.

Elias R.Z., Farag M. (2010), The relationship between accounting student's love of money and their ethical perception, "Managerial Accounting Journal”, vol. 25, issue 3, pp. 269-281, https://doi.org /10.1108/02686901011026369

Hajiha Z., Rajabdorri H. (2018), The Relationship between Islamic Work Ethics and Professional Ethics in Accounting Instructors, "Semiannual Journal of Islam and Management", vol. 6, no. 12, pp. 139-156, http://im.rihu.ac.ir/article_1496.html?lang=en (accessed: 30.08.2021). 
Hameed S., Yaya R. (2011), The emerging issues on the objectives and characteristics of Islamic accounting for Islamic business organizations, "Malaysian Accounting Review", vol. 4, no. 1, pp. 75-92.

Hossain M.K., Karim M.S., Islam S. (2008), A comparative analysis of conventional ethical code and Islamic ethcal code in accounting profession, "Thought on Economics", vol. 20, no. 1, pp. 39-53.

Iqbal M.Z., Molyneux P. (2005), Thirty Years of Islamic Banking, Palgrave Macmillan Studies in Banking and Financial Institutions, New York.

Jabłońska-Bonca J. (2005), Islam - prawo i finanse, [in:] H. Dzwonkowski, J. Głuchowski, A. Pomorska (eds.), $W$ kręgu prawa podatkowego i finansów publicznych, Wydawnictwo Uniwersytetu M. Curie-Skłodowskiej w Lublinie, Lublin, pp. 170-178.

Jackling B., Cooper B.J., Leung P., Dellaportas S. (2007), Professional accounting bodies' perception of ethical issues, causes of ethical failure and ethics education, "Managerial Auditing Journal", vol. 22, issue 9, pp. 928-944, https://doi.org/10.1108/02686900710829426

Jaworska E. (2011), Specyfika rachunkowości islamskiej. Wybrane zagadnienia, "Zeszyty Naukowe Uniwersytetu Szczecińskiego. Finanse, Rynki Finansowe, Ubezpieczenia”, vol. 625, no. 32, pp. 75-85.

Korenik D. (2010), Specyfika bankowości niekonwencjonalnej, [in:] A. Janc (ed.), Bankowość a kryzys na rynkach finansowych, "Zeszyty Naukowe Uniwersytetu Ekonomicznego w Poznaniu”, vol. 140, pp. 544-555.

Ladewi Y. (2014), The role of Islam values (ethics) in accounting practice and impact of accounting information quality: A library study, "International Journal of Economics, Commerce and Management", vol. 2, no. 12, pp. 1-12.

Lewis M.K. (2001), Islam and Accounting, "Accounting Forum", vol. 25, no. 2, pp. 103-127, https://www .tandfonline.com/doi/pdf/10.1111/1467-6303.00058 (accessed: 30.08.2021).

Low M., Davey H., Hooper K. (2008), Accounting scandals, ethical dilemmas and educational challenges, "Critical Perspectives on Accounting", vol. 19, issue 2, pp. 222-254, https://doi.org/10.1016/J.CPA .2006.05.010

Napier C. (2009), Defining Islamic accounting: current, issues, past and roots, "Accounting History", vol. 14, issue 1-2, pp. 121-144, https://doi.org/10.1177/1032373208098555

Noor Lela A., Ahmed H. (2017), The Acceptability and Impact of Sharia Foundation of Islamic Ethics in Accounting Education, "International Journal of Academic Research in Business and Social Sciences”, vol. 7, no. 2, pp. 494-506.

Noor Lela A., Ahmed H., Wan Salmuni W.M. (2017), The Significance of Islamic Ethics to Quality Accounting Practice, "International Journal of Academic Research in Business and Social Sciences”, vol. 7, no. 10, pp. 693-703.

Rahnema A. (1994), Islamic Economic Systems, Zed Books, New Jersey.

Saadeh Y., Alsmady A., Warrad L.H., Idris M., Elrajabi M.R. (2016), The Accounting Profession between Religious and Professional Ethical Codes, "International Journal of Business and Social Science", vol. 7, no. 10, pp. 35-43.

Sari Wahyuni I., Fernando Y., Hasnita E. (2018), Role of islamic ethics towards ethical accounting practice, "Journal of Governance and Integrity", vol. 2, no. 1, pp. 23-27, https://doi.org/10.15282 /jgi.2.1.2018.5535

Święty Koran. Tekst arabski i tłumaczenie polskie (1990), Islam International Publications Ltd., Islamabad. 


\section{Religia jako źródło etyki islamskiej i jej wpływ na system islamskiej rachunkowości}

Streszczenie: $\quad$ W artykule przedstawiono źródła religijne etyki muzułmańskiej oraz sposób, w jaki kształtuje ona system rachunkowości islamskiej i postępowanie muzułmańskich księgowych. Różnice kulturowe są istotnym czynnikiem, który należy brać pod uwagę w prowadzeniu firmy. Stanowią one przedmiot badań naukowych, również w kontekście ich wpływu na rozwój systemów rachunkowości w poszczególnych kręgach kulturowych. Do analizy jakościowej (metodą indukcji i dedukcji) wykorzystano literaturę referencyjną i Koran. $\mathrm{Z}$ analizy wynika, że choć kodeksy etyczne w krajach muzułmańskich i niemuzułmańskich są bardzo zbliżone pod względem treści, to w przypadku islamu ich przesłanie wzmacnia religia, która jest źródłem prawa, a także etyki zawodowej. Oznacza to, że sankcje prawne za łamanie zasad wiążą się z obawą przed wykluczeniem ze wspólnoty i utratą możliwości zbawienia. Artykuł ma charakter informacyjny, pozwala zrozumieć przyczyny pewnych różnic i ich znaczenie w postrzeganiu zagadnień etycznych i sposobu prowadzenia biznesu w różnych kręgach kulturowych.

Słowa kluczowe: etyka islamska, szariat, rachunkowość islamska JEL: $\quad$ M41, F69

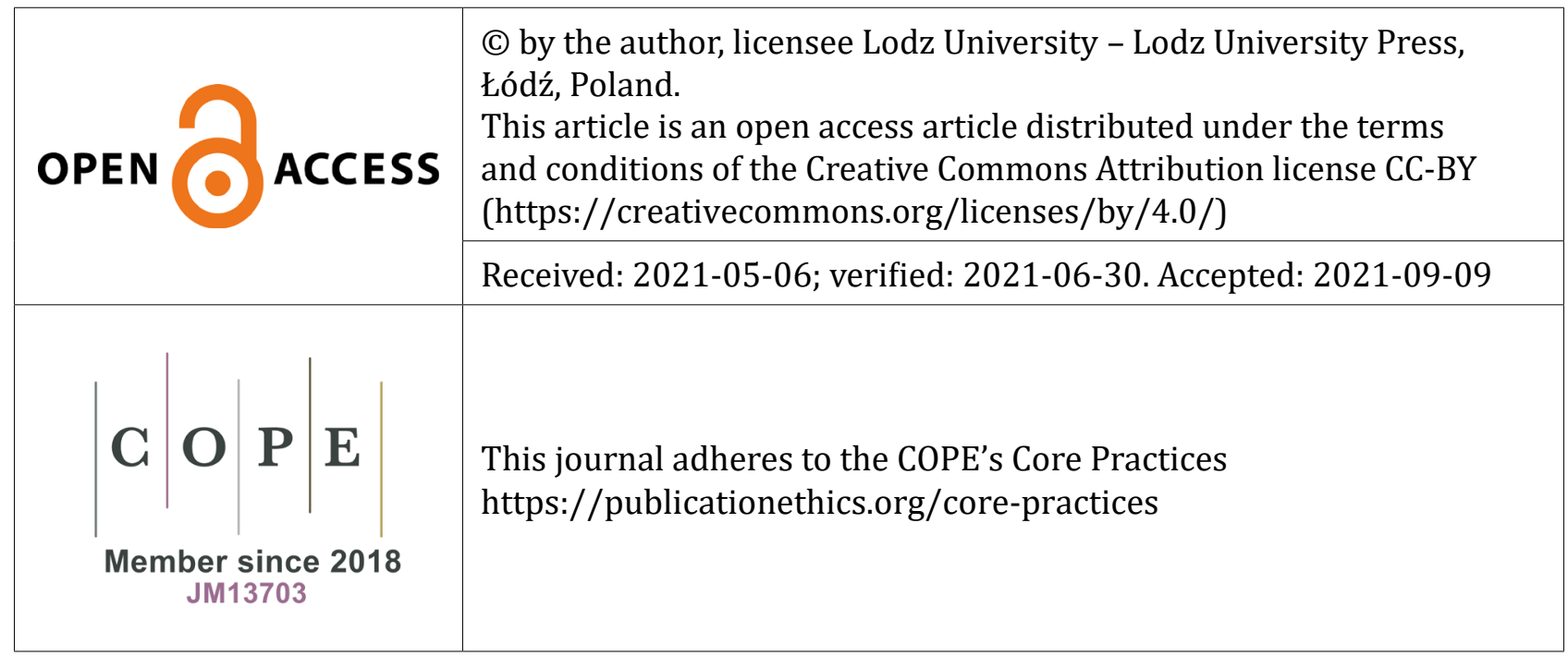

